

\title{
Efektivitas Penggunaan Bokashi Blotong Tebu dan Pemberian Pupuk Organik Cair Kulit Nanas Terhadap Produktifitas Tanaman Kecipir (Psophocarpus tetragonolobus L.)
}

\section{Effectivity of Sugarcane Bokashi and Liquid Organic fertilizer from Peanaple toward Cowpeas Growth and Productivity}

\author{
Muhammd Jusfar Simanjuntak 1), Syahbudin Hasibuan2), Maimunah1)*
}

1) Program Studi Agroteknologi, Fakultas Pertanian, Universitas Medan Area, Indonesia

\begin{abstract}
Abstrak
Tanaman kecipir sudah mulai dilupakan orang sehingga perlu dibudidayakan kembali. Penelitian ini bertujuan untuk mengetahui pertumbuhan dan produksi kecipir dengan penggunaan bokashi blotong tebu dan pemberian pupuk organik cair kulit. Metode penelitian yang digunakan dalam penelitian ini adalah Rancangan Acak Kelompok factorial dengan 2 (dua) faktor perlakuan Faktor bokashi blotong tebu (T) dan Faktor Pupuk Organik Cair kulit nanas (S). Setiap plot percobaan terdiri dari 8 tanaman dengan 4 tanaman sampel. Hasil dari penelitian ini menunjukkan bahwapenggunaan bokashi blotong tebu berpengaruh sangat nyata terhadap jumlah polong per sampel tetapi tidak berpengaruh nyata terhadap diameter batang, panjang polong persampel, berat polong persampel dan produksi perplot, pemberian pupuk organik cair kulit nanas berpengaruh sangat nyata terhadap jumlah polong persampel, tetapi tidak berpengaruh nyata terhadap diameter batang, panjang polong persampel, berat polong persampel dan produksi perplot, kombinasi antara penggunaan bokashi blotong tebu dan pemberian pupuk organik cair kulit nanas berpengaruh tidak nyata terhadap pertumbuhan dan produksi tanaman kecipir. Kata Kunci: kecipir, bokashi blotong tebu, POC kulit nanas
\end{abstract}

\begin{abstract}
Cowpeas is becoming rare, hence it has to be planted again to some reasons. This research aims to know the growth and production of cowpeas with Bokashi use of sugarcane filter cake and liquid organic fertilizer pineapple skin that have been implemented at the Faculty of Agriculture Experimental Station Road PBSI Area Terrain 1 Terrain Estate, District Percut Sei Tuan from March to July 2019. Methods the research in this research is a randomized block design factorial, with 2 (two) treatment factors, namely: 1) factors bokashi cane filter cake (T) and Organic Liquid Fertilizer Factors pineapple skin (S), each treatment was repeated 2 times so that there are 32 experimental plots. Each experimental plot consisted of eight plants with four plant samples. The results of this research indicate that the use of Bokashi blotong cane very significant effect on the number of pods persample but did not significantly affect stem diameter, length of pods persampel, heavy pods persampel and production perplot, fertilizer liquid organic pineapple skin very significant effect on the number of pods persampel, but did not significantly affect stem diameter, persampel pod length, pod weight and production persampel perplot, a combination of the use of sugarcane filter cake bokashi organic fertilizer liquid and pineapple skin no real effect on the growth and yield of cowpeas.
\end{abstract}

Keywords: Winged, Bokashi blotong cane, pineapple skin POC

How to Cite: Muhammad, J.S. Syahbudin, H. \& Maimunah. (2020). Efektivitas penggunaan bokashi blotong tebu dan pemberian pupuk organik cair kulit nanas terhadap pertumbuhan dan produksi tanaman kecipir (Psophocarpus tetragonolobus L.). Jurnal Ilmiah Pertanian (JIPERTA), 6 (2): 106-111

*E-mail: jusfar12@gmail.com




Muhammad Jusfa Simajuntak, Syahbudin Hasibuan \& Maimunah, Efektivitas penggunaan bokashi blotong tebu dan pemberian pupuk organik cair kulit nanas terhadap pertumbuhan dan produksi tanaman kecipir (Psophocarpus tetragonolobus L.)

\section{PENDAHULUAN}

Tanaman kecipir (Psophocarpus tertagonolobus L.) merupakan tanaman tropis yang mudah dibudidayakan. Tanaman kecipir sebenarnya sudah dikenal oleh masyarakat, karena umumnya buah mudanya dikonsumsi sebagai sayur (Z.N.A, 2018). Namun saat ini, tanaman ini telah banyak dilupakan dan tidak dimanfaatkan secara maksimal. Kecipir merupakan tanaman semusim tetapi umumnya dibiarkan menjadi tahunan dengan cara dipangkas. Tanaman ini mampu tumbuh dari dataran rendah sampai dataran tinggi, dan dapat beradaptasi dengan baik pada kondisi lingkungan yang kering. Masyarakat menanam kecipir sebagai tanaman pekarangan yang dibiarkan merambat pada pagar atau tanaman kayu lain (Handayani, 2013).

Kecipir termasuk tanaman yang mempunyai ciri khas yaitu terdapat buah yang disebut polong, yaitu buah yang berasal dari satu daun dengan atau tanpa sekat semu. Bila masak dan kering buah akan pecah, sehingga biji terlontar keluar atau buah terputus-putus menjadi beberapa bagian menurut sekat-sekat semunya. Diantara anggota yang lain, kecipir banyak mengandung zat gizi yang tinggi karena kandungan gizi seperti protein, lemak, dan vitamin dalam bijinya. Masyarakat juga memanfaatkan bagian-bagian tanaman kecipir sebagai bahan obat tradisional, misalnya untuk penambah nafsu makan, obat radang telinga, obat bisul, dan lain-lain. Sebagai supermarket on the stalk, kecipir merupakan sumber protein yang baik. Kandungan protein pada bunga 2,8-5,6; daun 5-7,6; polong muda 1,9-4,3; biji segar 4,6-10,7; biji kering 29,8-39 dan umbi 3-15, masing- masing dihitung sebagai gram per 100 gram bobot segar. Tingginya kandungan protein pada semua bagian tanaman kecipir mungkin berhubungan dengan kemampuan akar tanaman ini untuk mengikat nitrogen dari udara bebas (Krisnawati, 2010).

Besarnya potensi kecipir memberikan celah atau peluang untuk mengembangkan secara lebih terarah potensi komoditas ini. Usaha - usaha pengembangan komoditas tersebut antara lain melalui pemuliaan tanaman dan perbaikan teknik budidaya tanaman yang keduanya dapat dilakukan secara simultan. Komposisi protein total kecipir umumnya terdiri atas albumin, globulin, dan glutelin. Jika dilihat dari nilai kandungan pati dan protein, ubi kecipir memiliki potensi industri yang cukup besar yaitu sebagai bahan baku tepung kaya protein. Potensi ini jauh melebihi potensi ubi bengkuang yang hanya mengandung sekitar 0,8\% protein dan $3 \%$ pati (Nusifera dan Karuniawan, 2007).

Tanaman kecipir masih terpinggirkan dan belum dibudidayakan secara luas di Indonesia serta masih dilakukan secara tradisional sehingga ketersediaan benih di pasar terbatas. Terbatasnya ketersediaan benih ini dikarenakan belum tersedianya budidaya produksi benih bermutu. Salah satu faktor penting dalam usaha budidaya yang menunjang keberhasilan hidup dan produksi suatu tanaman adalah masalah pemupukan. Pupuk adalah material yang ditambahkan ke tanah atau tajuk tanaman dengan tujuan untuk melengkapi ketersediaan unsur hara. Pemberian pupuk organik dalam tingkat optimum perlu dilakukan secara terus menerus kepada tanaman yang 
akhirnya akan menaikkan potensi pertumbuhan dan produksi (Lingga dan Marsono, 2007).

Dengan meningkatnya limbah di indonesia maka menjadi sasaran untuk mendaur ulang menjadi pupuk organik karena limbah merupakan salah satu penyebab pencemaran lingkungan yang membawa dampak memburuknya kesehatan bagi masyarakat. Limbah yang dihasilkan oleh suatu industri dapat menimbulkan dampak negatif terhadap keseimbangan lingkungan apabila dibuang kesuatu badan air penerima (misalnya sungai) tanpa diolah terlebih dahulu. Apabila jumlah senyawa-senyawa yang terkandung dalam limbah melebihi kadar yang telah ditetapkan, maka air tersebut tidak dapat dipergunakan lagi untuk keperluan sebagaimana mestinya. Blotong, Limbah Kulit Nanas menjadi masalah yang serius bagi lingkungan masyarakat (Muhsin, 2011).

Blotong ampas tebu merupakan limbah yang paling tinggi tingkat pencemarannya dan menjadi masalah bagi pabrik gula dan masyarakat. Limbah ini biasanya dibuang kesungai dan menimbulkan pencemaran, karena didalam air bahan organik yang ada pada blotong akan mengalami penguraian secara alamiah, sehingga mengurangi kadar oksigen dalam air dan menyebabkan air bewarna gelap dan berbauk busuk (Purwaningsih, 2011; Ilyasa dkk, 2018).

Menurut Agustina (2008), ampas tebu merupakan limbah pertama yang dihasilkan dari proses pengolahan industri gula tebu volumenya mencapai 30-34\% dari tebu giling. Pemanfaatan limbah ampas tebu sebagai bahan baku pembuatan kompos merupakan salah satu alternatif untuk meminimalisir terjadinya polusi estetika. Serat bagas tidak dapat larut dalam air dan sebagian besar terdiri dari selulosa, pentosan, lignin dan juga memiliki kadar bahan organik sekitar 90\%, kandungan N 0.3\%, P205 0.02\%, K20 0.14\%, Ca $0.06 \%$, dan Mg 0.04\%. Hasil penelitian Riyanto (1995:2) menunjukkan bahwa pemberian kompos ampas tebu 4-6 ton/ha dapat mengurangi penggunaan pupuk NPK hingga $50 \%$.

Hasil penelitian Hasibuan et al., (2017) menunjukkan bahwa bokashi blotong tebu dapat meningkatkan tinggi tanaman kedelai umur 6 MST, perlakuan 10 ton ha-1 memberikan pertumbuhan dan hasil terbaik yaitu tinggi tanaman 52,08 cm, berat biji per tanaman 14,65 g, produksi per tanaman 40,70 g dan produksi per plot 0,90 kg. Data hasil penelitian Ilyasa et al., (2016) menunjukkan pemberian bokashi dari limbah ampas tebu juga dapat meningkatkan tinggi tanaman cabai rawit umur 6 MST, perlakuan 20 ton ha-1 memberikan pertumbuhan dan hasil terbaik yaitu tinggi tanaman $102 \mathrm{~cm}$, jumlah cabang per tanaman 11,6 cabang.

Timbunan limbah kulit nanas yang tidak terkendalikan yang kemudian berdampak negatif yang akan mempengaruhi berbagai segi kehidupan, baik secara langsung maupun tidak langsung. Pada permasalahan di lingkungan yang menjadi sumber bakteri penyakit, pencemaran udara, tanah, air, dan lebih jauh lagi terjadinya bencana ledakan gas metan, serta pencemaran udara akibat pembakaran terbuka yang menyebabkan pemanasan global. Kulit nanas merupakan limbah organik hasil sisa pembuangan produksi buah nanas yang mengandung beberapa senyawa yang dapat dijadikan produk olahan bermanfaat. Berdasarkan kandungan nutrisinya, kulit nanas dapat dijadikan sebagai bahan pembuatan pupuk organik. Menurut hasil penelitian Salim (2008) pupuk organik 
Muhammad Jusfa Simajuntak, Syahbudin Hasibuan \& Maimunah, Efektivitas penggunaan bokashi blotong tebu dan pemberian pupuk organik cair kulit nanas terhadap pertumbuhan dan produksi tanaman kecipir (Psophocarpus tetragonolobus L.)

dari kulit nanas mengandung unsur hara $0,70 \% \mathrm{~N}, 19,98 \% \mathrm{C}, 0,08 \% \mathrm{~S}, 0,03 \% \mathrm{Na}$, dengan pH 7,9. Berdasarkan uraian latar belakang diatas peneliti tertarik ingin melakukan penelitian dengan judul "Efektivitas Penggunaan Bokashi Blotong Tebu Dan Pemberian Pupuk Organik Cair Kulit Nanas Terhadap Pertumbuhan Dan Produksi Tanaman Kecipir (Psophocarpus tetragonolobus L.)

\section{METODE PENELITIAN}

\section{Rancangan Percobaan}

Penelitian dirancang dengan Rancangan Acak Kelompok Faktorial yang terdiri dari 2 faktor perlakukan. Faktor pertama yaitu Bokashi Blotong Tebu (T) dengan 4 tarap perlakuan. Faktor kedua yaitu konsentrasi POC Limbah Kulit Nanas (S) dengan 4 taraf perlakuan.

1. Bokashi Blotong Tebu terdiri dari 4 taraf, yaitu : $\mathrm{T} 0=0 \mathrm{Kg}$ Bokashi Blotong Tebu/Plot

T1 = $1 \mathrm{Kg}$ Bokashi Blotong Tebu/Plot

$\mathrm{T} 2=2 \mathrm{Kg}$ Bokashi Blotong Tebu /Plot

$\mathrm{T} 3=3 \mathrm{Kg}$ Bokashi Blotong Tebu /Plot

2. Pupuk Organik Cair Limbah Kulit Nanas terdiri dari 4 taraf, yaitu : S0 = Kontrol (Tidak menggunakan pupuk organik cair kulit nanas)

S1 = POC Limbah Kulit Nanas dengan konsentrasi 25\% (250 ml/750 ml air)

S2 = POC Limbah Kulit Nanas dengan konsentrasi 50\% (500 ml/500 ml air) S3 = POC Limbah Kulit Nanas dengan konsentrasi 75\% (750 ml/250 ml air).

Persiapan Pembuatan Bokashi Blotong Tebu dan POC Limbah Kulit Nanas

Dalam persiapan pembuatan pupuk bokashi dari limbah blotong tebu yaitu pengambilan bahan blotong tebu di Pabrik Gula Kwala Madu PTPN II, setelah itu melakukan pengumpulan limbah blotong tebu sebanyak $100 \mathrm{~kg}$, air secukupnya, dan EM4 1liter untuk mendekomposisi bahan organik, dan gula merah sebanyak $600 \mathrm{~g}$ sebagai bahan makanan mikroorganisme.

Pembuatan pupuk organik cair kulit nanas yang diawali dengan menyediakan limbah kulit nanas yang sudah dicincang sebanyak 8kg dan air sebanyak 40 liter lalu diletakkan didalam drum sebagai wadah fermentasi agar berlangsung lancar dan mencampurkan bahan 600 ggula merahdan EM4 sebanyak $600 \mathrm{ml}$, aduk sampai rata dan tercampur sempurna dan tutup dengan rapat. Perawatan dilakukan berupa pengadukan larutan setiap hari dan pupuk organik cair limbah kulit nanas akan matang setelah satu bulan dengan bau tape yang siap digunakan pada penelitian.

Persiapan Lahan, Penanaman dan Aplikasi

Pengolahan lahan dilakukan setelah rumput-rumput yang ada diareal pertanian dibersihkan terlebih dahulu dengan menggunakan cangkul, babat dan juga garu. Setelah keadaan lahan sudah benar-benar bersih maka dilakukan pengolahan tanah. Pengolahan tanah dilakukan dengan menggunakan traktor sedalam 20-30 cm kemudian tanah dibiarkan selama seminggu. Pengolahan tanah kedua dengan menghancurkan gumpalangumpalan tanah yang besar dengan menggunakan cangkul agar diperoleh tanah yang 
gembur. Pemberian Pupuk Bokashi Botong Tebu di aplikasikan 1 minggu sebelum tanam dengan dosis masing-masing sesuai perlakuan yang telah ditentukan yaitu $\mathrm{T} 0=0 \mathrm{Kg}$ Bokashi Blotong Tebu/Plot, T1= $1 \mathrm{Kg}$ Bokashi Blotong Tebu/Plot, T2= $2 \mathrm{Kg}$ Bokashi Blotong Tebu /Plot, T3 = $3 \mathrm{Kg}$ Bokashi Blotong Tebu /Plot. Pemberian pupuk bokashi blotong tebu dengan menaburkan diatas bedengan secara merata dengan tanah.

Sebelum dilakukan penanaman, biji kecipir terlebih dahalu direndam dengan air selama \pm 15 menit untuk mendorong proses imbibisi air kedalam biji. Penanaman dilakukan pada sore hari sekitar pukul 17.00 - 18.30 WIB. Penanaman dilakukan dengan membuat lubang tanam dan dimasukan 1 butir biji, lalu ditutup dengan tanah tipis dari biji yang telah ditanam. Pengampilkasian POC Kulit Nenas dilakukan pada umur 2 Minggu Setelah Tanam (MST) sampai dengan 7 MST atau 6 kali aplikasi. Pengamplikasian POC dari kulit nanas dilakukan dengan interval pemupukan 1 minggu sekali.

\section{Pengamatan dan Analisis Statistika}

Adapun data yang diamati dalam penelitian ini adalah diameter batang, jumlah polong per sampel, panjang polong persampel, bobot polong persampel, bobot polong per plot. Data tesebut kemudian dianalisis disesuakan dengan kaidah perhitungan RAK Faktorial 2 faktor.

\section{HASIL DAN PEMBAHASAN}

\section{Pengamatan dan Analisis Parameter Pertumbuhan Vegetatif}

Rataan rangkuman F.Hitung jumlah diameter batang kecipir umur 2 MST sampai 7 MST setelah penggunaanbokashi blotong tebu dan pemberian POC limbah kulit nanas disajikan pada tabel 1.

Table 1. Rangkuman F.Hitung Diameter Batang Tanaman Kecipir Persampel (cm) Pada Umur 2 - 7 MST Dengan Penggunaan Bokashi Blotong Tebu Dan Pemberian POC Kulit Nanas

\begin{tabular}{ccccccccc}
\hline & \multicolumn{9}{c}{$\mathrm{F}_{\text {Hitung }}$ Diameter batang } & \multicolumn{2}{c}{$\mathrm{F}_{\text {Tabel }}$} \\
\cline { 2 - 9 } SK & 2 & 3 & 4 & 5 & 6 & 7 & \multirow{2}{*}{$\mathrm{F}_{0.05}$} & $\mathrm{~F}_{0.01}$ \\
\hline MST & MST & MST & MST & MST & MST & & \\
\hline T & 0,58 tn & 1,77 tn & 1,41 tn & 2,49 tn & 0,95 tn & 1,74 tn & 3,29 & 5,42 \\
S & 0,58 tn & 0,31 tn & 0,81 tn & 0,83 tn & 0,88 tn & 1,47 tn & 3,29 & 5,42 \\
T x S & 0,78 tn & 0,45 tn & 0,41 tn & 0,54 tn & 0,63 tn & 0,72 tn & 2,59 & 3,89 \\
\hline
\end{tabular}

Keterangan $: \operatorname{tn}=$ tidak nyata.

Penggunaan bokashi blotong tebu (T)tidak berpengaruh nyata terhadap diameter batang pada umur 2 - 7 MST, dan pemberian POC kulit nanas (S) juga tidak berpengaruh nyata terhadap diameter batang dari umur 2-7 MST. Kombinasi antara kedua faktor perlakuan juga tidak berpengaruh nyata terhadap diameter batang tanaman kecipir dari umur 2 - 7 MST. Hasil analisis bokashi blotong tebu yang dilakukan di Laboratorium Pusat Penelitian Kelapa Sawit (2019), dengan hasil kandungan : N 1,28\%, P205 1,24\%, K20 0,12\%, C-organik 13,29\%, C/N $10,35 \%$ dan $\mathrm{pH} 6,62$. Sedangkan hasil analisis POC kulit nanas dengan hasil kandungan : N 0,76\%, P205 0,10\%, K20 0,07\%, C-organik 6,30\%, C/N 8,29 dan pH 5,92\%. Dari analisis yang dilakukan bahwa $\mathrm{C} / \mathrm{N}$ dari bokashi blotong tebu belum memenuhi kriteria yang bagus untuk di 
Muhammad Jusfa Simajuntak, Syahbudin Hasibuan \& Maimunah, Efektivitas penggunaan bokashi blotong tebu dan pemberian pupuk organik cair kulit nanas terhadap pertumbuhan dan produksi tanaman kecipir (Psophocarpus tetragonolobus L.)

aplikasikan pada tanaman, maka dari itu bokashi yang diaplikasikan belum sempurna untuk menambah unsur hara terhadap pertumbuhan dan perkembangan suatu tanaman.

Pada masa pertumbuhan dan perkembangan suata tanaman khususnya pada fase vegetatif seperti pertumbuhan batang dan daun, kandungan yang paling banyak dibutuhkan adalah kandungan nitrogen $(\mathrm{N})$, sebab unsur nitrogen dalam bokashi dan pupuk cair berperan penting dalam proses pembentukan klorofil yang berguna dalam proses fotosintesis. Proses fotosintesis ini berfunsi untuk memperoleh dan juga menghasilkan makanan bagi tanaman, dengan kandungan klorofil yang cukup dapat memacu pertumbuhan tanaman terutama dalam merangsang organ vegetatif pada suatu tanaman.

Rangkuman efektivitas dari kedua faktor perlakuan penggunaan bokashi blotong tebu dan berian POC kulit nanas serta kombinasi kedua faktor perlakuan dapat dilihat pada tabel 2 .

Table 2. Tabel Pertumbuhan Diameter Batang Tanaman Kecipir (cm) Umur 2-7 MST Dan Efektivitas Setelah Penggunaan Bokashi Blotong Tebu Dan Pemberian POC Kulit Nanas

\begin{tabular}{ccccc}
\hline Perlakuan & $\begin{array}{c}\text { Rataan Diameter Batang } \\
(\mathrm{cm})\end{array}$ & $\begin{array}{c}\text { Laju } \\
\text { Pertambahan \% }\end{array}$ & $\begin{array}{c}\text { Efektivitas } \\
(\%)\end{array}$ & R2 \\
\hline T0S0 & 1,01 & 0,187 & - & 0,958 \\
T0S1 & 0,96 & 0,179 & $-4,95$ & 0,925 \\
T0S2 & 0,91 & 0,151 & $-9,9$ & 0,967 \\
T0S3 & 1,08 & 0,189 & 6,93 & 0,985 \\
T1S0 & 0,71 & 0,114 & $-29,7$ & 0,954 \\
T1S1 & 0,91 & 0,165 & $-9,9$ & 0,958 \\
T1S2 & 0,84 & 0,152 & $-16,83$ & 0,963 \\
T1S3 & 0,86 & 0,157 & $-14,85$ & 0,966 \\
T2S0 & 0,78 & 0,130 & $-22,77$ & 0,967 \\
T2S1 & 0,9 & 0,151 & $-10,89$ & 0,953 \\
T2S2 & 1,05 & 0,184 & 3,96 & 0,988 \\
T2S3 & 0,91 & 0,174 & 9,9 & 0,951 \\
T3S0 & 0,75 & 0,123 & $-25,74$ & 0,979 \\
T3S1 & 0,76 & 0,134 & $-24,75$ & 0,974 \\
T3S2 & 1,01 & 0,182 & 0 & 0,977 \\
T3S3 & 0,91 & 0,156 & $-9,9$ & 0,948 \\
\hline
\end{tabular}

Dari tabel 4, dapat dijelaskan bahwa untuk faktor penggunaan bokashi blotong tebu (T) diperoleh bahwa laju pertambahan yang tertinggi terdapat pada perlakuan T2, dengan laju pertambahan 0,130\%, untuk faktor pemberian POC kulit nanas (S) diperolah bahwa perlakuan S3 merupakan perlakuan dengan laju pertumbuhan tertinggi, yakni sebesar 0,189 dan untuk kombinasi perlakuan diperoleh bahwa perlakuan T0S3 merupakan kombinasi dengan kelajuan pertumbuhan tertinggi, yakni sebesar $(0,189 \%)$. Sedangkan untuk efektivitas faktor bokashi blotong tebu diperoleh bahwa perlakuanT2 memiliki efektivitas tertinggi (22,77\%), untuk faktor POC kulit nanas diperoleh perlakuan S3 memilik efektivitas tertinggi (6,93\%) dan untuk kombinasi perlakuan diperoleh bahwa perlakuan T2S3 merupakan kombinasi dengan efektivitas tertinggi $(9,9)$.

Menurut Djunaedy (2009) bahwa tanaman muda akan dapat menyerap unsur hara dalam jumlah yang sedikit, sejalan dengan umur tanaman, kecepatan penyerapan unsur hara tanaman 
akan meningkat jika umur bertambah sesuai siklus hidupnya. Kualitas hidup tanaman juga sangat bergantung dari ketercukupan hara dari lingkungannya serta kemampuan akar tanaman dalam menyerap unsur hara dalam menunjang fase vegetatif tanaman. Seperti dikemukakan oleh Musnamar (2003) bahwa pupuk organik memiliki sifat lambat menyediakan unsur hara bagi tanaman karena memerlukan waktu untuk proses dekomposisinya. Menurut Muhammad (2014), bahwa pemberian bokasi ampas tebu tidak dapat dimanfaatkan secara efisiensi dan maksimal sehingga penyerapan unsur hara tidak akan berjalan lancar. Berapapun banyaknya unsur hara yang diberikan ke dalam tanah tidak akan pernah menjadi tanaman tumbuh subur, karena efektivitas penyerapan unsur hara sangat dipengaruhi oleh kadar bahan organik didalam tanah. Pertumbuhan dan perkembangan suatu tanaman berkaitan dengan erat dengan proses fotosintesis, yang akan menghasilkan fotosintat yang digunakan tanaman untuk proses pertumbuhannya hal ini dikarenakan sifat dari pupuk organik yang lambat terseda bagi tanaman.

Jumlah Polong Per Sampel (polong)

Rangkuman F. Hitung berdasarkan hasil data sidik ragam jumlah polong kecipir persampel dengan penggunaan bokashi blotong tebu dan pemberian POC kulit nanas dapat dilihat pada tabel 3.

Table 3. Rangkuman F.Hitung Jumlah Polong Tanaman Kecipir Persampel Dengan Penggunaan Bokashi Blotong Tebu dan Pemberian POC Kulit Nanas

\begin{tabular}{cccc}
\hline \multirow{2}{*}{ SK } & \multicolumn{3}{c}{ F. Hitung Jumlah Polong Persampel } \\
\cline { 2 - 4 } & Rataan & $\mathrm{F}_{0.05}$ & $\mathrm{~F}_{0.01}$ \\
\hline $\mathrm{T}$ & $41,34^{* *}$ & 3,29 & 5,42 \\
$\mathrm{~S}$ & $8,44^{* *}$ & 3,29 & 5,42 \\
T X S & $2,17 \mathrm{tn}$ & 2,59 & 3,89 \\
\hline
\end{tabular}

Keterangan $: \operatorname{tn}=$ tidak nyata $* *=$ sangat nyata

Dari tabel 3, dapat dilihat bahwa perlakuan bokashi blotong tebu (T) berpengaruh sangat nyata terhadap jumlah polong kecipir persampel dan POC kulit nanas (S) berpengaruh sangat nyata terhadap jumlah polong tanaman kecipir persampel, tetapi kombinasi antara kedua perlakuan tidak berpengaruh nyata terhadap jumlah polong tanaman kecipir persampel.

Sangat nyatanya jumlah polong kecipir dari hasi peneliti ini karena tanaman kecipir merupakan tanaman yang masa berbunga terus menerus. Polong kecipirterbentuk dari ovarium yang telah terserbuki dengan baik berkisar 2-5 polong per malai dengan rata-rata 3 polong per malai. Dengan demikian hampir semua bunga mekar dapat berkembang menjadi polong, serta disebebkan unsur hara yang terkadung didalam perlakuanbokashi blotong tebu dan POC kulit nanas mencukupi parameter jumlah polong.

Rangkuman efektivitas dari kedua faktor perlakuan penggunaan bokashi blotong tebu dan pemberian POC kulit nanas serta kombinasi kedua faktor perlakuan dapat dilihat pada tabel 4 . 
Muhammad Jusfa Simajuntak, Syahbudin Hasibuan \& Maimunah, Efektivitas penggunaan bokashi blotong tebu dan pemberian pupuk organik cair kulit nanas terhadap pertumbuhan dan produksi tanaman kecipir (Psophocarpus tetragonolobus L.)

Table 4. Tabel Efektivitas Jumlah Polong Tanaman Kecipir Setelah Penggunaan Bokashi Blotong Tebu Dan Pemberian POC Kulit Nanas

\begin{tabular}{ccc}
\hline Perlakuan & Rataan Jumlah Polong & Evektivitas (\%) \\
\hline T0S0 & 5,04 & - \\
T0S1 & 5,17 & 2,47 \\
T0S2 & 5,46 & 8,26 \\
T0S3 & 6,00 & 19,00 \\
T1S0 & 6,25 & 23,96 \\
T1S1 & 6,25 & 23,96 \\
T1S2 & 6,21 & 23,14 \\
T1S3 & 6,54 & 29,75 \\
T2S0 & 6,04 & 19,83 \\
T2S1 & 6,25 & 23,96 \\
T2S2 & 6,42 & 27,27 \\
T2S3 & 6,13 & 21,48 \\
T3S0 & 6,33 & 25,62 \\
T3S1 & 6,25 & 23,96 \\
T3S2 & 6,42 & 27,27 \\
T3S3 & 6,92 & 37,19 \\
\hline
\end{tabular}

Dari tabel 4, dapat dijelaskan bahwa untuk efektivitas faktor bokashi blotong tebu diperoleh bahwa perlakuan T3 memiliki efektivitas tertinggi, yakni 25,62\%, untuk faktor POC kulit nanas diperoleh perlakuan S3 memiliki efektivitas tertinggi, yakni 19,00\% dan untuk kombinasi kedua perlakuan diperoleh bahwa T3S3 merupakan kombinasi dengan efektivitas tertinggi, yakni 37,19\%. Menurut Sondakh, dkk., (2012) bahwa unsur makro N, P, K mempunyai peranan masing-masing untuk tanaman diantaranya unsur nitrogen dibutuhkan untuk pertumbuhan dan pembentukan batang serta cabang. Unsur fosfor diperlukan bagi tanaman untuk perkembangan biji dan akar. Sementara unsur kalium berfungsi untuk membentuk bunga dan buah serta membantu tanaman melawan penyakit.

\section{Panjang Polong Persample}

Rangkuman F. Hitung berdasarkan hasil data sidik ragam panjang polong kecipir persampel dengan penggunaan bokashi blotong tebu dan pemberian POC kulit nanas dapat dilihat pada tabel 5 .

Table 5. Rangkuman F.Hitung Panjang Polong Tanaman $(\mathrm{cm})$ kecipir Persampel Dengan Penggunaan Bokashi Blotong Tebu dan Pemberian POC Kulit Nanas 


\begin{tabular}{cccc}
\hline \multirow{2}{*}{ SK } & \multicolumn{3}{c}{$\mathrm{F}_{\text {Hitung }}$ Panjang Polong Persampel $(\mathrm{g})$} \\
\cline { 2 - 4 } & Rataan & $\mathrm{F}_{0.05}$ & $\mathrm{~F}_{0.01}$ \\
\hline $\mathrm{T}$ & $0,44 \mathrm{tn}$ & 3,29 & 5,42 \\
$\mathrm{~S}$ & $1,00 \mathrm{tn}$ & 3,29 & 5,42 \\
$\mathrm{~T} \mathrm{X} \mathrm{S}$ & $1,28 \mathrm{tn}$ & 2,59 & 3,89 \\
\hline
\end{tabular}

Keterangan $:$ tn $=$ tidak nyata

efektivitas faktor penggunaan bokashi blotong tebu diperoleh bahwa perlakuan T3 memiliki efektivitas tertinggi, yakni $(3,08 \%)$, untuk faktor pemberian POC kulit nanas diperoleh perlakuan S2 memiliki efektivitas tertinggi, yakni $(6,22 \%)$ dan untuk kombinasi kedua perlakuan diperoleh bahwa T2S3 merupakan kombinasi dengan efektivitas tertinggi, yakni $(8,52 \%)$.

penggunaan bokashi blotong tebu hanya 1 kali aplikasi untuk kebutuhan 8 tanaman per plot selama \pm 3 bulan penelitian, tanpa ada penambahan pupuk lanjutan. Hal ini dapat dibuktikan dari hasil analisis bokashi blotong tebu yang dilakukan di Laboratorium Pusat Penelitian Kelapa Sawit (2019), dengan hasil kandungan: N 1,28\%, P205 1,24\%, K20 0,12\%, C-organik 13,29\%, C/N 10,35\% dan pH 6,62 (Lampiran 72). Sedangkan hasil analisis POC kulit nanas dengan hasil kandungan: N 0,76\%, P205 0,10\%, K20 0,07\%, C-organik 6,30\%, C/N 8,29 dan pH 5,92\%. Unsur hara didalam tanah tergolong rendah terutama unsur $\mathrm{P}$ dan $\mathrm{K}$, sedangkan unsur hara pada bokashi dan $\mathrm{POC}$ tergolong juga rendah.Dalam kaitannya dengan parameter panjang polong, bobot polong dan produksi perplot tanaman memerlukan unsur $\mathrm{P}$ dan $\mathrm{K}$ yang lebih banyak untuk merangsang pembentukan bunga dan polong.

Menurut Sondakh, dkk., (2012) bahwa unsur makro N, P, K mempunyai peranan masing-masing untuk tanaman diantaranya unsur nitrogen dibutuhkan untuk pertumbuhan dan pembentukan batang serta cabang. Unsur fosfor diperlukan bagi tanaman untuk perkembangan biji dan akar. Sementara unsur kalium berfungsi untuk membentuk bunga dan buah serta membantu tanaman melawan penyakit. Sesuai dengan pernyataan (Fefiani, 2014) yang menyatakan bahwa ketersedian unsur hara yang dapat diserap oleh tanaman mempengaruhi tinggkat produktivitas tanaman. Sedangkan menurut (lubis, 2013) ketersediaan unsur hara yang dapat diserap oleh tanaman merupakan salah satu faktor yang dapat mempengaruhi tingkat produktivitas suatu tanaman. Pada dasarnya jenis dan jumlah unsur hara yang tersedia didalam tanah harus cukup dan seimbang untuk pertumbuhan agar tingkat produktivitas yang diharapkan dapat tercapai.

\section{Bobot Polong Per Sampel}

Rangkuman F. Hitung berdasarkan hasil data sidik ragam bobot polong kecipir persampel (g) dengan penggunaan bokashi blotong tebu dan pemberian POC kulit nanas dapat dilihat pada tabel 6 .

Table 6. Rangkuman F.Hitung Bobot Polong Tanaman Kecipir Persampel (g) Dengan Penggunaan Bokashi Blotong Tebu dan Pemberian POC Kulit Nanas 
Muhammad Jusfa Simajuntak, Syahbudin Hasibuan \& Maimunah, Efektivitas penggunaan bokashi blotong tebu dan pemberian pupuk organik cair kulit nanas terhadap pertumbuhan dan produksi tanaman kecipir (Psophocarpus tetragonolobus L.)

\begin{tabular}{cccc}
\hline \multirow{2}{*}{$\mathrm{SK}$} & \multicolumn{4}{c}{$\mathrm{F}_{\text {Hitung }}$ Bobot Polong Persampel (gr) } \\
\cline { 2 - 4 } & Rataan & $\mathrm{F}_{0.05}$ & $\mathrm{~F}_{0.01}$ \\
\hline $\mathrm{T}$ & $0,42 \mathrm{tn}$ & 3,29 & 5,42 \\
$\mathrm{~S}$ & $0,35 \mathrm{tn}$ & 3,29 & 5,42 \\
$\mathrm{~T} \mathrm{X} \mathrm{S}$ & $0,54 \mathrm{tn}$ & 2,59 & 3,89 \\
\hline
\end{tabular}

Keterangn : tn $=$ tidak nyata

perlakuan bokashi blotong tebu (T) menunjukkan tidak berpengaruh nyata terhadap panjang polong tanaman kecipir dan perlakuan POC kulit nanas (S) juga menujukkan tidak berpengaruh nyata terhadap panjang polong tanaman kecipir. Interakasi antara kedua perlakuan juga tidak berpengaruh nyata terhadap panjang polong tanaman kecipir.

Efektivitas faktor bokashi blotong tebu diperoleh bahwa perlakuan T3 memiliki efektivitas tertinggi, yakni 5,22\%, untuk faktor POC kulit nanas diperoleh perlakuan S2 memiliki efektivitas tertinggi, yakni $4,89 \%$ dan untuk kombinasi kedua perlakuan diperoleh bahwa T3S3 merupakan kombinasi dengan efektivitas tertinggi, yakni 15,18\%. Menurut Sondakh, dkk., (2012) bahwa unsur makro N, P, K mempunyai peranan masingmasing untuk tanaman diantaranya unsur nitrogen dibutuhkan untuk pertumbuhan dan pembentukan batang serta cabang. Unsur fosfor diperlukan bagi tanaman untuk perkembangan biji dan akar. Sementara unsur kalium berfungsi untuk membentuk bunga dan buah serta membantu tanaman melawan penyakit.

Perlakuan bokashi blotong tebu (T) menunjukkan pengaruh tidak nyata terhadap bobot polong tanaman kecipir perplot dan perlakuan POC kulit nanas (S) juga menujukkan pengaruh tidak nyata terhadap bobot polong tanaman kecipir perplot. Interakasi antara kedua perlakuan juga tidak berpengaruh nyata terhadap bobot polong tanaman kecipir perplot. Menurut Sondakh, dkk., (2012) bahwa unsur makro N, P, K mempunyai peranan masing-masing untuk tanaman diantaranya unsur nitrogen dibutuhkan untuk pertumbuhan dan pembentukan batang serta cabang. Unsur fosfor diperlukan bagi tanaman untuk perkembangan biji dan akar. Sementara unsur kalium berfungsi untuk membentuk bunga dan buah serta membantu tanaman melawan penyakit.

\section{SIMPULAN}

Dari hasil penelitian yang telah dilakukan dapat diambil beberapa kesimpulan sebagai berikut: Penggunaan bokashi blotong tebu tidak berpengaruh nyata terhadap diamater batang dari umur 2-7 MST, panjang polong, bobot polong persampel dan produksi perplot, tetapi berpengaruh sangat nyata terhadap jumlah polong kecipir. Pemberian pupuk organik cair limbah kulit nanas tidak berpengaruh nyata terhadap diameter batang, bobot polong persampel, dan produksi perlot, tetapi berpengaruh sangat nyata terdapat jumlah polong kecipir. Perlakuan antara kombinasi penggunaan bokashi blotong tebu dan pemberian pupuk organik cair kulit nanas berpengaruh tidak nyata terhadap diameter batang, jumlah polong persampel, panjang polong, bobot polong persampel dan produksi perplot 


\section{DAFTAR PUSTAKA}

Agustina. Ali Jamil. Rizqi Sari, A. 2008. Potensi Limbah Tebu Hasil Industri Sebagai Bahan Pupuk Organik Lokal di Lahan Kering Dataran Rendah Iklim Basah. Balai Pengkajian Teknologi Pertanian Riau, Pekanbaru.

Djunaedy, A. 2009. Pengaruh Dosis Pupuk Bokashi terhadap Pertumbuhan dan Hasil Kacang Panjang (Vigna sinensis L.). Agrivigor Vol 2(1): 42-46

Fefiani Y, \& Barus WA. (2015). Respon pertumbuhan dan produksi tanaman Mentimun (Cucumis sativus L.) akibat pemberian pupuk kandang sapi dan pupuk organik padat Supernasa. AGRIUM: Jurnal Ilmu Pertanian, 19(1).

Handayani T, Kusmana K, Lukman L, \& Hidayat IM. (2016). Karakterisasi morfologi dan evaluasi daya hasil sayuran polong kecipir (Psophocarpus tetragonolobus (L.) DC). Jurnal Hortikultura, 25(2), 126-132.

Harahap, Nigita. 2014. Pembuatan pupuk organik cair Limbah Kulit Nenas. Program Studi Pascasarjana Pendidikan Kimia, Universitas Negeri Semarang. Semarang.

Ilyasa, M., Hutapea, S., \& Rahman, A. (2018). Respon Pertumbuhan dan Produksi Tanaman Cabai Rawit (Capsicum frutescens L) terhadap Pemberian Kompos dan Biochar dari Limbah Ampas Tebu. Agrotekma: Jurnal Agroteknologi dan Ilmu Pertanian, 3(1), 39-49.

Krisnawati A. (2016). Keragaman genetik dan potensi pengembangan kecipir (Psophocarpus tetragonolobus L.) di Indonesia. Jurnal Penelitian dan Pengembangan Pertanian, 29(3), 113-119.

Lingga P. (2001). Petunjuk penggunaan pupuk: Niaga Swadaya.

Lubis E, \& Barus WA. (2015). Respon Pertumbuhan dan Produksi Kedelai (Glycine max L.) akibat Pemberian Limbah Padat (Sludge) Kelapa Sawit dan Pupuk Cair Organik. AGRIUM: Jurnal Ilmu Pertanian, 18(2).

Muhammad SA, \& Noor R. J. 2014. Pengaruh Jenis dan Dosis Pupuk Organik kompos Olahan Biogas terhadap Pertumbuhan dan Hasil tanaman Terung (Solanum melongena L.) Varietas Mustang F-1. Jurnal Agrifor, 13(1), 59-66.

Muhsin A. (2011). Pemanfaatan limbah hasil pengolahan pabrik tebu blotong menjadi pupuk organik.

Musnamar EI. (2003). Pembuatan dan Aplikasi Pupuk Organik Padat. Penebar Swadaya, Jakarta.

Nusifera S, \& Karuniawan A. (2007). Potensi Hasil dan Kualitas Hasil Ubi 16 Genotip Bengkuang (Pachyrhizus erosus L. Urban) di Jatinangor pada Dua Musim. Prosiding Simposium PERAGI IX di Bandung, 15-17.

Purwaningsih C. (2011). Pengaruh pemberian kompos blotong, legin, dan mikoriza terhadap serapan hara $\mathrm{N}$ dan $\mathrm{P}$ tanaman kacang tanah. Widya Warta: Jurnal Ilmiah Universitas Katolik Widya Mandala Madiun, 35(02), 55-68.

Rahmah, Atikah., Izzati, Munifatul ,. dan Sarjana Parman. 2014. Pengaruh Pupuk Organik Cair Berbahan Dasar Limbah kulit nenas Terhadap Pertumbuhan Tanaman Jagung Manis (Zea Mays L. Var. Saccharata).Semarang : Universitas Diponegoro

Unga NT. (2019). PENGARUH DOSIS PUPUK BOKASHI TERHADAP PERTUMBUHAN DAN HASIL TANAMAN MELON (Cucumis Melo L.). Universitas Tadulako, 